\title{
A meta-analysis on Omega-3 supplements in preventing recurrence of atrial fibrillation
}

\author{
Ying Jiang ${ }^{1}$, Hui Ching Tan², Wilson Wai San Tam¹, Toon Wei Lim³ and Wenru Wang ${ }^{1}$ \\ ${ }^{1}$ Alice Lee Centre for Nursing Studies, Yong Loo Lin School of Medicine, National University of Singapore, Singapore \\ ${ }^{2}$ Department of Nursing, National University Hospital, Singapore \\ ${ }^{3}$ National University Hospital, Assistant Professor, Yong Loo Lin School of Medicine, National University of Singapore, \\ Singapore \\ Correspondence to: Wenru Wang, email: nurww@nus.edu.sg \\ Keywords: Omega-3 polyunsaturated fatty acids; recurrence of atrial fibrillation; meta-analysis \\ Received: September 12,2017 Accepted: December 26, $2017 \quad$ Published: December 30, 2017 \\ Copyright: Jiang et al. This is an open-access article distributed under the terms of the Creative Commons Attribution License 3.0 \\ (CC BY 3.0), which permits unrestricted use, distribution, and reproduction in any medium, provided the original author and source \\ are credited.
}

\section{ABSTRACT}

Previous studies had suggested that Omega-3 fatty acids have pleiotropic effects and favourable safety profile, which may potentially increase the efficacy of antiarrhythmic drugs in suppressing atrial arrhythmias through combination therapy. This meta-analysis aimed to determine the effectiveness of using Omega-3 polyunsaturated fatty acids as a sole anti-arrhythmic agent or as an adjunct to existing pharmacological therapies in preventing atrial fibrillation recurrence. Randomized controlled trials published in English, from inception to December 2016, were considered. We searched for published studies in the following electronic databases: Cochrane Central Register of Controlled Trials, PubMed, EMBASE, Medline, Scopus, and Cumulative Index to Nursing and Allied Health Literature. Pooled hazard ratio (HR) and corresponding $95 \%$ confidence intervals (CI) for time to first atrial fibrillation recurrence was analysed using a fixed effects model. Four RCTs with 1,268 participants were included in the review. Our results showed that Omega-3 polyunsaturated fatty acid therapy had no effect on preventing atrial fibrillation recurrence compared to control/placebo group (HR: 1.13, 95\% CI: 0.96 to $1.33, p=$ 0.14 ), with no significant heterogeneity found among those studies ( $Q$ value $=0.15$, $\left.9=0.99, I^{2}=0 \%\right)$. Therefore, current evidence does not support treatment benefit of Omega-3 fatty acids in preventing atrial fibrillation recurrence among patients who have not been treated by any conventional reversion treatment, or who have only been treated with pharmacological therapy.

\section{INTRODUCTION}

Atrial fibrillation (AF) is the commonest sustained cardiac arrhythmia affecting approximately 33.5 million individuals worldwide [1]. Although well tolerated in most patients, AF is associated with an increased longterm risk of stroke and all-cause mortality [2]. With an ageing population, the prevalence of $\mathrm{AF}$ is expected to increase, therefore, efforts to control this global epidemic is required [3].
Common treatment options to restore sinus rhythm (SR), otherwise known as rhythm control, consist of both pharmacological and non-pharmacological strategies, of which the latter includes electrical cardioversion, catheter ablation and surgical ablation [4]. Although evidence support the efficacy of non-pharmacological methods in rhythm control, the recurrence rate of AF after treatment with non-pharmacological strategies remains high [5]. Compared to pharmacological therapy, the invasive nature of non-pharmacological interventions is associated with 
poorer tolerability, higher costs [6], and concerns about the risk of life-threatening complications such as pericardial tamponade [4, 7]. As such, antiarrhythmic drugs (AADs) may be preferred in reducing cost and promoting ease of treatment.

AADs can be used alone or as an adjunct therapy to restore and maintain SR [8]. Evidence on the efficacy of AADs as a sole treatment modality is however limited [9], with 1 -year success rates ranging between $30 \%$ to $65 \%$ as compared to $74 \%$ to $90 \%$ for radiofrequency catheter ablation [7]. This has led to the question of whether it is possible to enhance the efficacy of AADs in long-term suppression of arrhythmias through combination therapy [10].

There has been an increased attention on the potential benefits of non-antiarrhythmic agents such as Omega-3 polyunsaturated fatty acid in AF management. Omega-3 polyunsaturated fatty acid, also commonly known as fish oil products, are concentrated sources of eicosapentaenoic acid and docosahexaenoic acid (DHA). It has been proposed that Omega-3 polyunsaturated fatty acid possess antiinflammatory properties that can inhibit arrhythmogenic mechanisms $[11,12]$, as inflammation results in oxidative stress, apoptosis and fibrosis which promote AF substrate formation and arrhythmogeneicity [13].

A number of trials have been carried out to test the potential role of Omega-3 polyunsaturated fatty acid in treating AF, but findings have been inconsistent [14-17]. In the reviews by Mariani et al. [18], He et al. [19], Cao et al. [20] and Liu et al. [21], prevention of secondary AF was limited in the treatment modality employed. Electrical cardioversion was the most common treatment and the outcomes were equivocal across all these studies. Given the disadvantages of non-pharmacological approaches, it is thus a suboptimal approach to preventing AF recurrences. Hence, pharmacological options may still be preferred if efficacy can be increased. Apart from the possible antiarrhythmic benefits that Omega-3 polyunsaturated fatty acid can offer to AF patients, it is also worth investigating the effects of Omega-3 polyunsaturated fatty acid supplementation as an adjunct to AAD therapy in preventing AF recurrence. To the best of our knowledge, no review has been done specifically on this topic thus far. Therefore, this review aimed to determine the effectiveness of using Omega-3 polyunsaturated fatty acid as a sole anti-arrhythmic agent or as an added therapy to existing pharmacological therapies in preventing the recurrence of AF. In particular, we examined the rate of AF recurrence, measured by time to first recurrent episode as the primary outcome for this review.

\section{RESULTS}

\section{Studies identification}

The PRISMA flow chart is presented in Figure 1. The initial search across the databases identified 1,038 records. After removal of duplicates, 728 records were screened, of which 675 were excluded after screening the title and 36 were excluded after screening the abstract because they were ineligible. The full texts were retrieved for the remaining 17 records. Subsequently after screening the full texts, 13 articles were excluded for reasons as shown in Figure 1. In total, four RCT studies were included for this meta-analysis [15, 17, 22, 23].

\section{Description of included studies}

The summaries of the included studies are presented in Table 1. Of the four included studies, three were prospective, double-blind, placebo-controlled, parallel arm RCTs [17, 22, 23], and the other study was a prospective, open-label randomized study [15]. The studies were published in the United States, Australia and Canada. In total, there were 1268 participants involved in those studies, of which $56 \%$ were male. Participants in the intervention group had a mean age of $64.95 \pm 8.76$ years old, while participants in the control group had a mean age of $65.30 \pm 7.82$ years old. Three studies prescribed $4 \mathrm{~g}$ of omega-3 polyunsaturated fatty acid per day, which contained approximately 1.60 to $1.86 \mathrm{~g} /$ day EPA and 0.8 to $1.50 \mathrm{~g} /$ day DHA (the active components) as study intervention $[17,22,23]$. The other study by Kumar et al. prescribed $6 \mathrm{~g}$ /day of omega- 3 polyunsaturated fatty acid that contained approximately $1.02 \mathrm{~g} /$ day EPA and 0.72 $\mathrm{g} /$ day DHA [15]. Two studies had a loading period of 7 days and 21 days $[22,23]$, while the other two studies did not. The intervention duration and follow up duration varied across the studies, ranging from 6 months or less (stopped when first AF recurrent episode occurred) [17] to up to 16 months [23].

\section{Risk of bias}

Figure 2 is a summary of the risk of bias assessment for the included studies. Overall, the risk of bias among these studies was low. However, half of the studies did not provide details on the methods for random sequence generation or mention the implementation of allocation concealment. One study adopted an open label design and outcome data were retrieved in an un-blinded fashion [15], therefore incurring a higher risk of bias than the other three studies. All the studies reported the use of intention to treat to manage missing values and reported their outcomes of interest completely.

\section{Meta-analysis}

Figure 3 shows a forest plot of the pooled hazard ratio (HR) of AF recurrence in the participants who received omega-3 polyunsaturated fatty acid compared to those who did not. When results were combined, omega-3 polyunsaturated fatty acid therapy had no effect 
in preventing AF recurrence compared to control/placebo group (HR: $1.13,95 \% \mathrm{CI}: 0.96$ to $1.33, p=0.14$ ), with no significant heterogeneity found among those studies ( $Q$ value $\left.=0.15,9=0.99, \mathrm{I}^{2}=0 \%\right)$.

In fact, none of the included RCTs showed a significant difference in time to first AF recurrence between the intervention and control group. Among the low-risk patients with paroxysmal or persistent AF who have never received conventional anti-arrhythmic therapy, Omega-3 fatty acids did not show any rhythm-control benefits [23]. In the highrisk pacemaker population, long-term high dose Omega-3 fatty acids use was associated with shorter episodes of AF recurrence compared to the control group, but no differences in the frequency of recurrent episodes was found [15]. Furthermore, two studies reported that Omega- 3 fatty acids did not result in any significant changes in the concentrations of inflammatory or oxidative stress markers as compared to controls [17, 23]. Moreover, the high dose of Omega-3 fatty acids was poorly tolerated by the treatment group [15].

\section{DISCUSSION}

To the best of our knowledge, this is the first metaanalysis to examine the effects of Omega-3 fatty acids as a sole anti-arrhythmic agent or as a supplementation to AADs in preventing AF recurrence. The review included four RCTs involving 1,268 participants across three countries. Result revealed that Omega-3 polyunsaturated fatty acid has no beneficial effect on AF recurrence among patients who have not been treated by any conventional rhythm control treatment, or who have only been on pharmacological therapy.

An earlier cohort study of 4815 participants had found that consumption of tuna and other broiled or baked fish with increased plasma phospholipid longchain n-3 fatty acids level was linked to a lower incidence of AF [24]. However, subsequent cohort studies with larger sample sizes failed to replicate the result $[25,26]$. Similarly, although animal experimental studies suggest

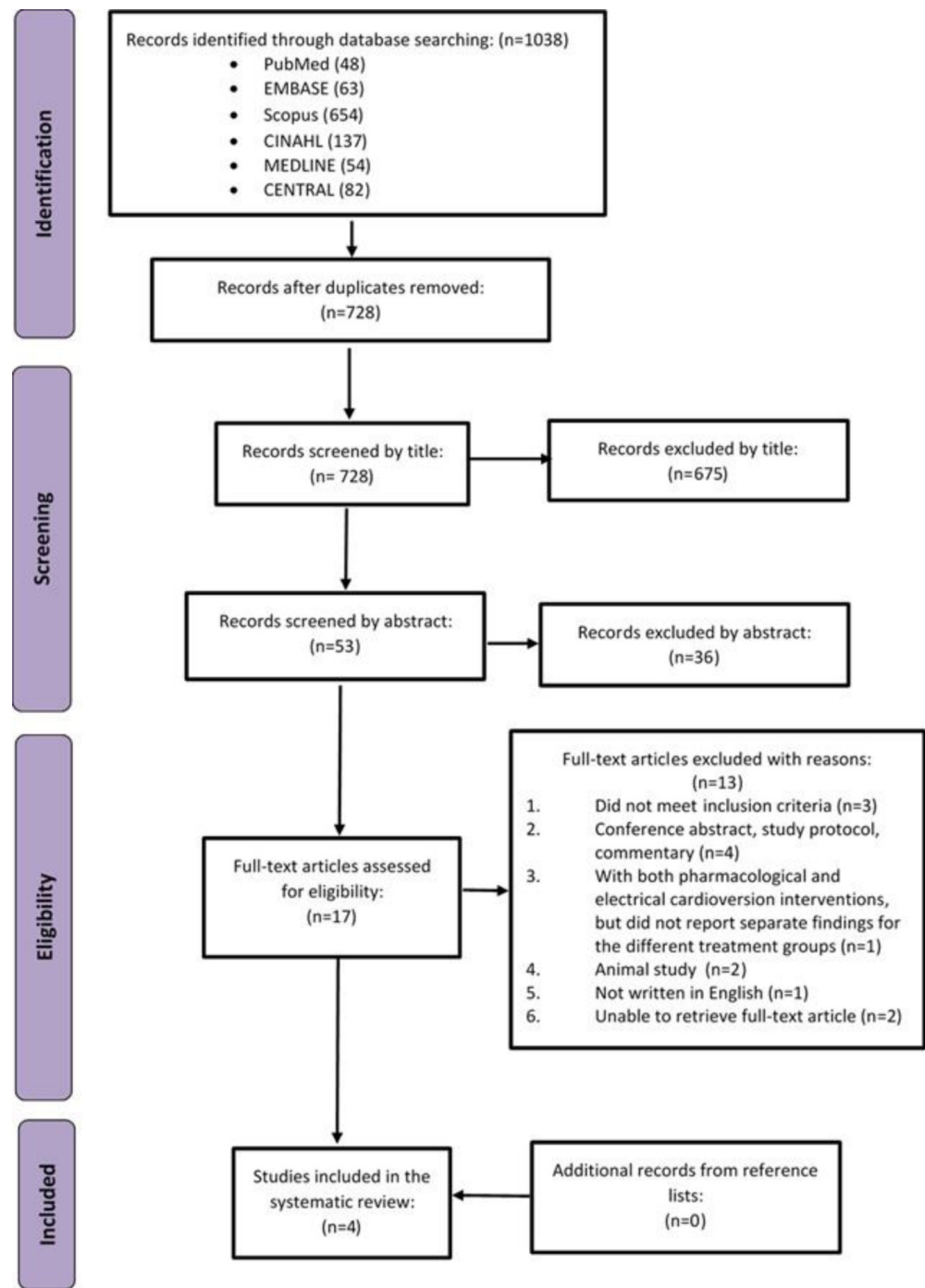

Figure 1: PRISMA flow diagram. 
Table 1: Summaries of included studies

\begin{tabular}{|c|c|c|c|c|c|c|c|c|c|c|c|}
\hline Authors & $\begin{array}{l}\text { Study } \\
\text { design }\end{array}$ & Participants & Intervention & Control & $\begin{array}{l}\text { Use of } \\
\text { AADs }\end{array}$ & $\begin{array}{l}\text { Intervention } \\
\text { description }\end{array}$ & $\begin{array}{c}\text { Control } \\
\text { description }\end{array}$ & $\begin{array}{l}\text { Follow-up } \\
\text { assessment }\end{array}$ & Definition of AF & Method to measure & Findings \\
\hline $\begin{array}{l}\text { Kumar } \\
\text { et al. (2013) }\end{array}$ & $\begin{array}{l}\text { Open- } \\
\text { label }\end{array}$ & $\begin{array}{l}\text { AF patients } \\
\text { aged } \geq 60 \\
\text { years with } \\
\text { sinoatrial } \\
\text { node disease } \\
\text { and dual } \\
\text { pacemakers }\end{array}$ & $\begin{array}{c}N=39 \\
\text { Mean age }= \\
78(7)\end{array}$ & $\begin{array}{l}N=39 \\
\text { Mean age } \\
=77(8)\end{array}$ & Yes & $\begin{array}{c}\text { Omega-3 } \\
\text { dosage: } 6 \mathrm{~g} / \\
\text { day }(1.02 \mathrm{~g} \\
\text { EPA and } \\
0.72 \mathrm{~g} \text { DHA) } \\
\text { Duration: } 6 \\
\text { month and } 12 \\
\text { month } \\
\text { Loading: No }\end{array}$ & $\begin{array}{l}\text { Not given } \\
\text { placebo, but } \\
\text { instructions } \\
\text { not to } \\
\text { commence } \\
\text { omega-3 } \\
\text { supplements } \\
\text { and maintain } \\
\text { a stable } \\
\text { omega-3 } \\
\text { intake }\end{array}$ & $\begin{array}{l}6 \text { month and } \\
12 \text { month }\end{array}$ & $\begin{array}{l}\text { A-A interval } \\
\text { irregularity on } \\
\text { marker channels } \\
\text { and/or fibrillatory } \\
\text { activity on EGMs } \\
\text { or ECG }\end{array}$ & $\begin{array}{c}\text { Intracardiac } \\
\text { EGMs and marker } \\
\text { channels. An ECG } \\
\text { was performed } \\
\text { if a patient was } \\
\text { noted to have } \\
\text { atrial arrhythmia } \\
\text { at the time of } \\
\text { interrogation. }\end{array}$ & $\begin{array}{l}\text { At } 6 \text { months, } \\
\text { time to first } \\
\text { episode of AT/AF } \\
\text { not significant } \\
\text { between } 2 \\
\text { groups. } \\
\text { At } 12 \text { months, } \\
\text { rebound increase } \\
\text { in AT/AF burden } \\
\text { in cross-over } \\
\text { patients }(p= \\
0.01) \text {, reached } \\
\text { a level similar } \\
\text { to controls ( } p= \\
0.63) \text {, and higher } \\
\text { than those who } \\
\text { continued with } \\
\text { fish oil ( } p= \\
0.02) \text {. } \\
\text { Fish oil patients } \\
\text { had shorter } \\
\text { episodes of } \\
\text { AT/AF, with } \\
\text { no difference } \\
\text { in frequency } \\
\text { compared to } \\
\text { control. }\end{array}$ \\
\hline $\begin{array}{l}\text { Darghosian } \\
\text { et al. (2015) }\end{array}$ & $\begin{array}{l}\text { Double } \\
\text { blind }\end{array}$ & $\begin{array}{l}\text { AF patients } \\
\text { with a history } \\
\text { of at least } 2 \\
\text { occurrences } \\
\text { of AF or } \\
\text { atrial flutter. }\end{array}$ & $\begin{array}{c}N=126 \\
\text { Mean age }= \\
62(12)\end{array}$ & $\begin{array}{l}N=64 \\
\text { Mean age } \\
=61(11)\end{array}$ & Yes & $\begin{array}{c}\text { Omega-3 } \\
\text { dosage: } 4 \mathrm{~g} / \\
\text { day }(1.86 \mathrm{~g} \\
\text { EPA and } 1.5 \mathrm{~g} \\
\text { DHA) } \\
\text { Duration: } 6 \\
\text { months or less } \\
\text { (AF recurred) } \\
\text { Loading: No }\end{array}$ & Corn oil & $\begin{array}{l}6 \text { months } \\
\text { or until } \mathrm{AF} \\
\text { recurred }\end{array}$ & $\begin{array}{l}\text { ECG were coded, } \\
\text { and evaluated by } \\
2 \text { blinded cardiac } \\
\text { electrophysiologists }\end{array}$ & $\begin{array}{l}\text { eCardio Post- } \\
\text { Event Recorder } \\
\text { (transtelephonic } \\
\text { electrocardiographic } \\
\text { monitor } \\
\text { device), routine } \\
\text { transmissions } \\
\text { every } 2 \text { weeks and } \\
\text { if had symptoms } \\
\text { suggestive of } \\
\text { arrhythmia }\end{array}$ & $\begin{array}{l}\text { No significant } \\
\text { difference in time } \\
\text { to AF recurrence, } \\
\text { even after taking } \\
\text { into consideration } \\
\text { age, race, gender, } \\
\text { randomization } \\
\text { stratum (AADs), } \\
\text { CHD, CHF, and } \\
\text { duration of AF } \\
\text { (HR }=1.20,95 \% \\
\text { CI: } 0.76-1.90, p \\
=0.438) \text {. } \\
\text { Intervention was } \\
\text { not associated } \\
\text { with clinically } \\
\text { important effects } \\
\text { on concentrations } \\
\text { of markers of } \\
\text { inflammation and } \\
\text { oxidative stress } \\
\text { either. }\end{array}$ \\
\hline $\begin{array}{l}\text { Kowey } \\
\text { et al. (2010) }\end{array}$ & $\begin{array}{l}\text { Double } \\
\text { blind }\end{array}$ & $\begin{array}{c}\text { Patients with } \\
\text { symptomatic } \\
\text { paroxysmal } \\
\text { or persistent } \\
\text { AF }\end{array}$ & $\begin{array}{c}N=266^{\mathrm{a}} \\
\text { Mean age }= \\
60.0(13.56)\end{array}$ & $\begin{array}{c}N=276^{\mathrm{a}} \\
\text { Mean age } \\
=61.9 \\
(11.57)\end{array}$ & No & $\begin{array}{c}\text { Omega-3 } \\
\text { dosage: } 4 \mathrm{~g} / \\
\text { day }(1.86 \mathrm{~g} \\
\text { EPA and } \\
1.38 \mathrm{~g} \text { DHA) } \\
\text { Duration: } 6 \\
\text { months } \\
\text { Loading: } 8 \mathrm{~g} / \\
\text { day for the } \\
\text { first } 7 \text { days }\end{array}$ & $1 \mathrm{~g}$ corn oil & 6 months & no mention & $\begin{array}{l}\text { Biweekly } \\
\text { transtelephonic } \\
\text { monitoring }\end{array}$ & $\begin{array}{l}\text { Among patients } \\
\text { with paroxysmal } \\
\text { AF, } 6 \text { months } \\
\text { treatment with } \\
\text { prescription } \\
\text { omega- } 3 \text { did not } \\
\text { reduced recurrent } \\
\text { AF compared } \\
\text { with placebo } \\
\text { group }\end{array}$ \\
\hline $\begin{array}{l}\text { Nigam } \\
\text { et al. (2014) }\end{array}$ & $\begin{array}{l}\text { Double } \\
\text { blind }\end{array}$ & $\begin{array}{l}\text { Patients with } \\
\text { symptomatic } \\
\text { paroxysmal } \\
\text { or persistent } \\
\mathrm{AF}\end{array}$ & $\begin{array}{c}N=153 \\
\text { Mean age }= \\
60(12)\end{array}$ & $\begin{array}{l}N=163 \\
\text { Mean age } \\
=62(13)\end{array}$ & No & $\begin{array}{c}\text { Omega-3 } \\
\text { dosage: } 4 \mathrm{~g} / \\
\text { day }(1.6 \mathrm{~g} \\
\text { EPA and } 0.8 \mathrm{~g} \\
\text { DHA) } \\
\text { Duration: } 6 \\
\text { months to } 16 \\
\text { months (or till } \\
\text { first AF) } \\
\text { Loading: } 4 \mathrm{~g} / \\
\text { day for the } \\
\text { first } 3 \text { week }\end{array}$ & $\begin{array}{l}1 \mathrm{~g} \text { safflower } \\
\text { oil }\end{array}$ & $\begin{array}{l}6 \text { months to } \\
16 \text { months (or } \\
\text { less, till first } \\
\text { AF) }\end{array}$ & $\begin{array}{l}\text { Asymptomatic or } \\
\text { symptomatic } \mathrm{AF} \\
\text { recurrence lasting } \\
\geq 30 \mathrm{~s}\end{array}$ & $\begin{array}{c}\text { Monitor weekly } \\
\text { transtelephonic } \\
\text { monitor } \\
\text { transmissions, } \\
12 \text { lead ECG or } \\
\text { implanted device. }\end{array}$ & $\begin{array}{c}\text { Omega-3 did } \\
\text { not reduce } \mathrm{AF} \\
\text { recurrence in } \\
\text { patients with a } \\
\text { history of AF } \\
\text { not receiving } \\
\text { conventional AA } \\
\text { therapy. }\end{array}$ \\
\hline
\end{tabular}

aparoxysmal AF stratum (who had never treated by long-term pharmacological or electrical therapy) 
that omega-3 fatty acids possess anti-arrhythmic properties of [27-30], results from clinical trials have been disappointing.

Our results are in line with previous systematic reviews and meta-analyses examining the effects of Omega-3 polyunsaturated fatty acid on the secondary prevention of AF after electrical cardioversion [18-21] and in AF prevention in patients undergoing heart surgery $[18,31]$. The discrepancies between experimental studies and clinical trials could be partly attributed to publication bias, in which positive results of animal studies were more likely to be published compared to those with negative findings [20]. Other plausible reasons may include a chance effect of small sample size from these earlier animal studies (sample sizes ranging from 8 to 24) [27, 28, $30]$, the significantly much smaller remodeling capacity of an animal heart [19], the higher doses used in the animal experiments and the different route of administration (intravenous vs oral) resulting in discrepant bioavailability [27].

Several mechanisms have been recognized in the pathogenesis of $\mathrm{AF}$, and among these, the role of inflammation and oxidative stress is believed to be fundamental in the pathophysiology of atrial remodeling

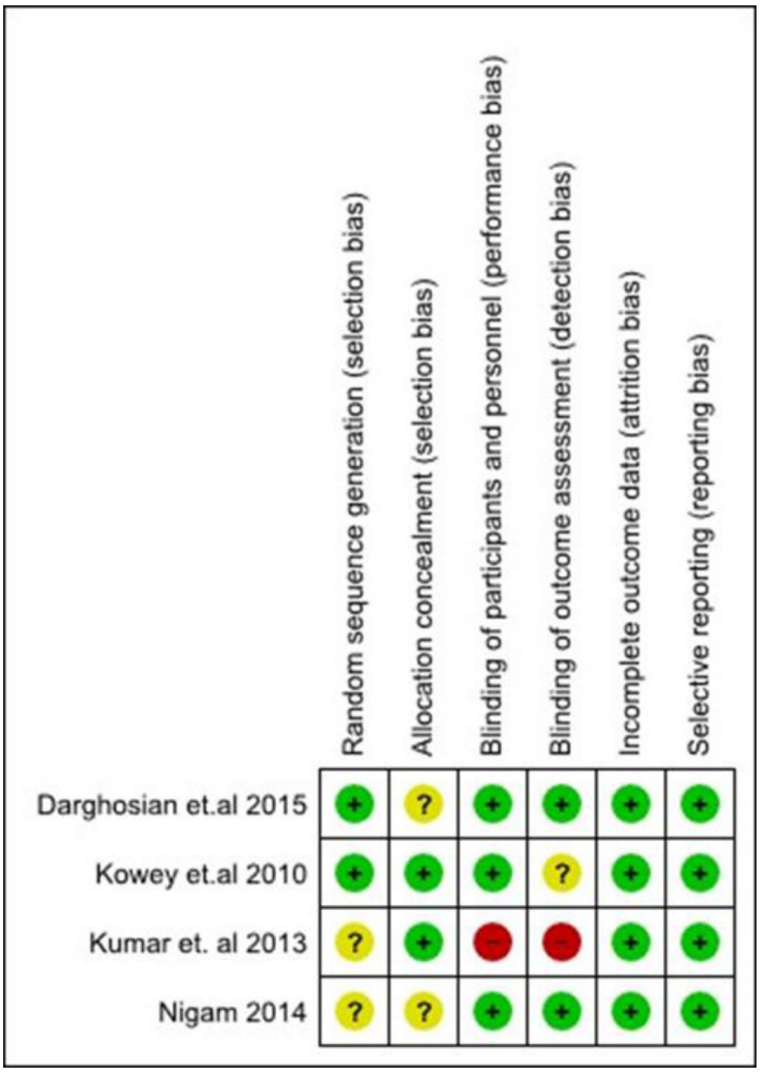

Figure 2: Risk of bias summary.

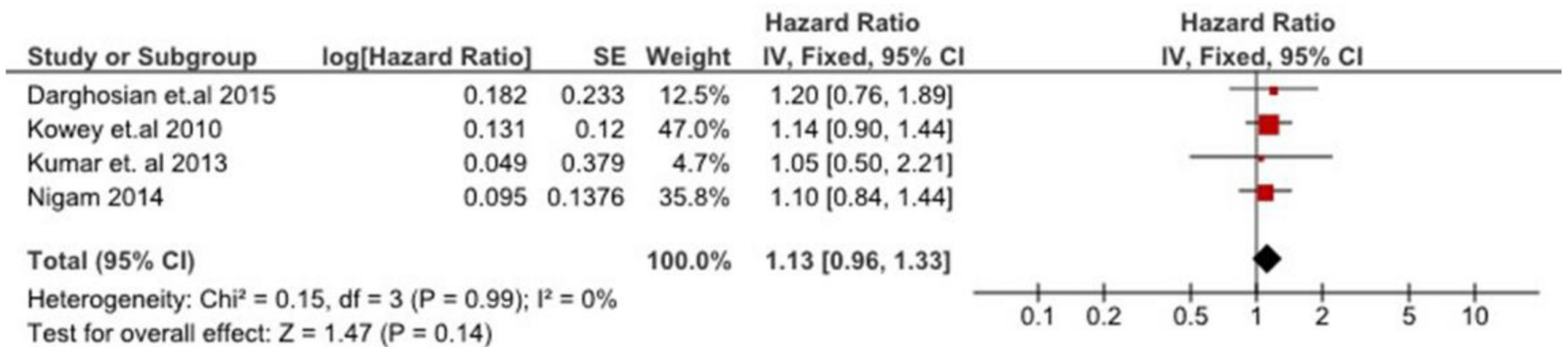

Figure 3: Effect of omega-3 polyunsaturated fatty acid on time to first AF recurrent episode. 
[17, 32, 33]. Evidence from previous research suggested that Omega-3 fatty acid lowers systematic inflammation and oxidative stress by preventing the catalysis of arachidonic acid into potent inflammatory aggregators and suppressing important inflammatory mediators, such as interleukin (IL)-1 $\beta$, tumor necrosis factor and IL-6 $[11,12]$. However, these findings have not been consistent. Despite the relatively large sample sizes and high doses of Omega-3 fatty acid, Darghosian et al. [17] and Nigam et al. [23] found that Omega-3 fatty acid had no effect in reducing inflammation or oxidative stress as measured though serum biomarkers [17], c-reactive protein (CRP) and myeloperoxidase (MPO) [23] compared to controls. Therefore, the inability of Omega- 3 fatty acid to reduce AF recurrence could be due to the absence of a clinically relevant effect on the underlying pathophysiological processes [23].

In addition, although it has been found that omega-3 fatty acids may have better antiarrhythmic potential when it is incorporated into cell membranes [34], the complex interaction between circulating and tissue levels of omega-3 fatty acids and its resulting effects are not fully understood [21]. Metcalf et al. [35] suggested that omega-3 supplementation in human subjects gave a slow and gradual increase in tissue levels over 2 months, while plasma levels rose shortly and remained constant. Therefore, a short course of supplementation may not have allowed sufficient incorporation of omega-3 fatty acids into cardiac tissues to show an effect [21]. In the study by Kowey et al. [22] a loading phase of 7 days was included, but it was noted that nearly half of the participants who received omega- 3 fatty acids experienced AF recurrence within the 56 days (first 2 months) of omega-3 consumption, which may suggest insufficient time for building up tissue levels.

\section{LIMITATIONS}

Our review has several limitations. Firstly, we limited our review to only one outcome, which was time to first $\mathrm{AF}$ recurrence as measured by hazard ratio. Therefore, potential benefits of Omega-3 fatty acid in AF prevention measured by other outcomes or clinical indicators, such as the frequency of AF episodes and the duration of each episode, were not captured. Secondly, we only included randomized studies in the review and articles written in English. As a result, only four studies were included, and the population in these studies were strictly defined. This may not have been a true reflection of the clinical profile of all AF patients in the community. Therefore, caution should be exercised when extrapolating our results to wider clinical settings. Thirdly, because of the limited number of studies, when analyzing the effect of Omega
3 fatty acids in combination with ADDs, we could not stratify the effect based on the types of ADDs.

\section{CONCLUSIONS AND CLINICAL IMPLICATION}

Omega-3 fatty acid, with its pleiotropic effects and favorable safety profile has been proposed as a potential adjunct to augment the efficacy of AADs for suppressing arrhythmias. However, this present meta-analysis showed that Omega-3 fatty acid consumption either as a supplement to AADs or as a sole anti-arrhythmic agent is not associated with a reduction in AF recurrence. Therefore, there is insufficient evidence to support its routine use in either role.

\section{METHODS}

The study followed the preferred reporting items for systematic reviews and meta-analyses (PRISMA) guideline [36].

\section{Inclusion criteria}

We included studies that were randomized controlled trials (RCTs), which met the following inclusion criteria: 1) Study participants were adult patients with a confirmed diagnosis of AF. 2) The arrhythmia had been treated by either exclusively pharmacological means or with no treatment prior to the point of study enrolment, and patients were in sinus rhythm before study initiation. 3) Studies that evaluated the effects of Omega-3 fatty acids as a sole anti-arrhythmic agent or as a supplement to AADs in preventing AF recurrence. 4) Studies that separated participants into at least one group receiving Omega-3 fatty acids treatment and one group receiving a placebo treatment or no treatment. 5) Studies that included the recurrence of AF as the study outcome.

\section{Exclusion criteria}

We excluded studies in which the intervention was a form of primary prevention in patients who had not been diagnosed with AF and studies with overlapping study populations (such as participants had been previously treated with drugs or electrical cardioversion therapy), but did not report separate findings for the different treatment groups.

\section{Search strategy}

The search strategy comprised of a three-step approach. First, a preliminary search in Cochrane and 
MEDLINE was conducted to identify permutations of text words and index terms contained in the title and abstracts used to describe articles. Second, a literature search was conducted by the first two authors (JY and HC) using the identified keywords and index terms on the following databases to identify the published studies: Cochrane Central Register of Controlled Trials (CENTRAL), PubMed, EMBASE, Medline, Scopus, and Cumulative Index to Nursing and Allied Health Literature (CINAHL). The keywords used included: omega 3, polyunsaturated fatty acid*, PUFA, n-3 fatty acid*, eicosapentaenoic acid*, EFA, alpha-linolenic acid*, docosahexaenoic acid*, DHA, fish oil, atrial fibrillation, atrial arrhythmia*, auricular fibrillation*, auricular arrhythmia*, atrium fibrillation*, atrium arrhythmia*. The search strategy is presented in the Appendix. The search was limited to English studies conducted from inception to December 2016. Lastly, the reference lists from the included articles were hand searched to identify other potentially relevant articles.

\section{Study selection}

Two independent authors (JY and HC) screened the title and abstract of the records retrieved from the databases to identify the potentially relevant studies. After which, the full texts of potentially relevant studies were retrieved and critically appraised based on the inclusion and exclusion criteria before being included in the review. Disagreements were resolved through discussion between the two primary reviewers.

\section{Primary outcomes}

The recurrence of AF, measured as time to first recurrent episode was the primary outcome for this review.

\section{Data extraction}

Study characteristics, such as research design, participants' characteristics, intervention description, reported outcomes, and statistical parameters, such as sample size, hazard ratio were extracted using a structured data extraction form adapted from the Cochrane Handbook for Systematic Reviews of Interventions [37]. Two reviewers (JY and WW) reviewed the studies independently, and summary tables were discussed to ensure the accuracy and relevance of the extracted data.

\section{Assessment of risk of bias}

Two independent assessors (JY and WW) assessed the risk of bias of the included studies based on the Cochrane Collaboration tool for assessment of risk of bias described in the Cochrane Handbook for Systematic Reviews of Interventions [37]. The following criteria were assessed: (1) random sequences generation (selection bias), (2) allocation concealment (selection bias), (3) blinding of participants and personnel (performance bias), (4) blinding of outcome assessment (detection bias), (5) incomplete outcome data (attrition bias), and (6) selective reporting (reporting bias). Differences between the two reviewers were resolved through discussion to reach a consensus.

\section{Data syntheses and analyses}

AF recurrence as measured by time to first recurrent episode was expressed in Hazard Ratio (HR) with 95\% CI. The natural logarithm and the standard error of the HR were computed for each study. The fixed effect and random-effects models using inverse variance approach were adopted in the absence and presence of heterogeneity respectively. Heterogeneity among the studies was evaluated by the Cochran's $Q$ test and $\mathrm{I}^{2}$ statistic. The $p$-value of the Cochran's $Q$ test was set at $<0.1$ to suggest statistical heterogeneity. $\mathrm{I}^{2}$ statistic was used to estimate the percentage of variation across the studies that is due to heterogeneity, with $75 \%, 50 \%, 25 \%$, or $0 \%$ indicating high, moderate, low, or no heterogeneity, respectively [38]. The overall effect was assessed by Z-statistic. The significance level was set at $p<0.05$. Computations for the meta-analysis were conducted using the RevMan software (Review Manager Version 5.3 for Windows from The Nordic Cochrane Centre, The Cochrane Collaboration, 2014) [37]. Subgroup analysis would be conducted to explore the source of heterogeneity when necessary.

\section{Abbreviations}

AADs: antiarrhythmic drugs; AF: atrial fibrillation; CENTRAL: Cochrane Central Register of Controlled Trials; CINAHL: Cumulative Index to Nursing and Allied Health Literature; DHA: docosahexaenoic acid; HF: hazard ratios; RCTs: Randomized controlled trials.

\section{Author contributions}

Ying Jiang: Conduct literature search, perform metaanalysis and draft manuscript; Hui Ching Tan: Conduct literature search and prepare the manuscript; Wilson Wai San Tam: perform meta-analysis, interpret the results, and critically revise the paper; Toon Wei Lim: critical revision of the paper; Wenru Wang: Design and conceptualize the study, prepare the manuscript, and critically revise the paper.

\section{CONFLICTS OF INTEREST}

The authors declare no conflicts of interest. 


\section{FUNDING}

This work was supported by National University Health System (NUHS) Bridging Grant (Grant Number: NUHSRO/2016/017/Bridging/01 and National Medical Research Council, Ministry of Health Singapore, Health Service Research Grant (Grant Number: HSRGWS16Jul007).

\section{REFERENCES}

1. Chugh SS, Havmoeller R, Narayanan K, Singh D, Rienstra M, Benjamin EJ, Gillum RF, Kim YH, McAnulty JH Jr, Zheng ZJ, Forouzanfar MH, Naghavi M, Mensah GA, et al. Worldwide epidemiology of atrial fibrillation: a Global Burden of Disease 2010 Study. Circulation. 2014; 129:83747. https://doi.org/10.1161/circulationaha.113.005119.

2. Singh SN. Costs and clinical consequences of suboptimal atrial fibrillation management. ClinicoEconomics and outcomes research: CEOR. 2012; 4:79.

3. Wolowacz S, Samuel M, Brennan V, Jasso-Mosqueda JG, Van Gelder I. The cost of illness of atrial fibrillation: a systematic review of the recent literature. Europace. 2011; 13:1375-85.

4. Kirchhof P, Benussi S, Kotecha D, Ahlsson A, Atar D, Casadei B, Castella M, Diener HC, Heidbuchel H, Hendriks J. 2016 ESC Guidelines for the management of atrial fibrillation developed in collaboration with EACTS. European heart journal. 2016; 37:2893-962.

5. Lafuente-Lafuente C, Longas-Tejero MA, Bergmann JF, Belmin J. Antiarrhythmics for maintaining sinus rhythm after cardioversion of atrial fibrillation. Cochrane Database Syst Rev. 2012; 5.

6. Kim MH, Johnston SS, Chu BC, Dalal MR, Schulman KL. Estimation of total incremental health care costs in patients with atrial fibrillation in the United States. Circulation: Cardiovascular Quality and Outcomes. 2011; 4:313-20.

7. Neyt M, Van Brabandt H, Devos C. The cost-utility of catheter ablation of atrial fibrillation: a systematic review and critical appraisal of economic evaluations. BMC cardiovascular disorders. 2013; 13:78.

8. Vizzardi E, Curnis A, Latini MG, Salghetti F, Rocco E, Lupi L, Rovetta R, Quinzani F, Bonadei I, Bontempi L. Risk factors for atrial fibrillation recurrence: a literature review. Journal of Cardiovascular Medicine. 2014; 15:235-53.

9. Zimetbaum P. Antiarrhythmic drug therapy for atrial fibrillation. Circulation. 2012; 125:381-9.

10. Singh BN. Augmenting maintenance of sinus rhythm in the control of atrial fibrillation by antiarrhythmic drug combinations. Journal of cardiovascular pharmacology and therapeutics. 2010; 15:31S-5S.

11. Surette ME. The science behind dietary omega-3 fatty acids. Canadian Medical Association Journal. 2008; 178:177-80.

12. Yashodhara B, Umakanth S, Pappachan J, Bhat S, Kamath R, Choo B. Omega-3 fatty acids: a comprehensive review of their role in health and disease. Postgraduate medical journal. 2009; 85:84-90.

13. Harada M, Van Wagoner DR, Nattel S. Role of inflammation in atrial fibrillation pathophysiology and management. Circulation journal. 2015; 79:495-502.

14. Kumar S, Sutherland F, Morton JB, Lee G, Morgan J, Wong J, Eccleston DE, Voukelatos J, Garg ML, Sparks PB. Longterm omega-3 polyunsaturated fatty acid supplementation reduces the recurrence of persistent atrial fibrillation after electrical cardioversion. Heart rhythm. 2012; 9:483-91.

15. Kumar S, Sutherland F, Stevenson I, Lee JM, Garg ML, Sparks PB. Effects of long-term omega-3 polyunsaturated fatty acid supplementation on paroxysmal atrial tachyarrhythmia burden in patients with implanted pacemakers: Results from a prospective randomised study. International journal of cardiology. 2013; 168:3812-7.

16. Nodari S, Triggiani M, Campia U, Manerba A, Milesi G, Cesana BM, Gheorghiade M, Dei Cas L. n-3 Polyunsaturated Fatty Acids in the Prevention of Atrial Fibrillation Recurrences After Electrical Cardioversion. Circulation. 2011; 124:1100-6.

17. Darghosian L, Free M, Li J, Gebretsadik T, Bian A, Shintani A, McBride BF, Solus J, Milne G, Crossley GH. Effect of omega-three polyunsaturated fatty acids on inflammation, oxidative stress, and recurrence of atrial fibrillation. The American journal of cardiology. 2015; 115:196-201.

18. Mariani J, Doval HC, Nul D, Varini S, Grancelli H, Ferrante D, Tognoni G, Macchia A. N-3 polyunsaturated fatty acids to prevent atrial fibrillation: updated systematic review and meta-analysis of randomized controlled trials. Journal of the American Heart Association. 2013; 2:e005033.

19. He Z, Yang L, Tian J, Yang K, Wu J, Yao Y. Efficacy and safety of omega-3 fatty acids for the prevention of atrial fibrillation: a meta-analysis. Canadian Journal of Cardiology. 2013; 29:196-203.

20. Cao H, Wang X, Huang H, Ying SZ, Gu YW, Wang T, Huang CX. Omega-3 fatty acids in the prevention of atrial fibrillation recurrences after cardioversion: a meta-analysis of randomized controlled trials. Internal medicine. 2012; 51:2503-8.

21. Liu T, Korantzopoulos P, Shehata M, Li G, Wang X, Kaul S. Prevention of atrial fibrillation with omega-3 fatty acids: a meta-analysis of randomised clinical trials. Heart. 2011: hrt. 2010.215350.

22. Kowey PR, Reiffel JA, Ellenbogen KA, Naccarelli GV, Pratt CM. Efficacy and safety of prescription omega-3 fatty acids for the prevention of recurrent symptomatic atrial fibrillation: a randomized controlled trial. Jama. 2010; 304:2363-72.

23. Nigam A, Talajic M, Roy D, Nattel S, Lambert J, Nozza A, Jones P, Ramprasath VR, O'Hara G, Kopecky S. Fish oil for the reduction of atrial fibrillation recurrence, inflammation, and oxidative stress. Journal of the American College of Cardiology. 2014; 64:1441-8. 
24. Mozaffarian D, Psaty BM, Rimm EB, Lemaitre RN, Burke GL, Lyles MF, Lefkowitz D, Siscovick DS. Fish intake and risk of incident atrial fibrillation. Circulation. 2004; 110:368-73.

25. Berry JD, Prineas RJ, van Horn L, Passman R, Larson J, Goldberger J, Snetselaar L, Tinker L, Liu K, Lloyd-Jones DM. Dietary fish intake and incident atrial fibrillation (from the Women's Health Initiative). The American journal of cardiology. 2010; 105:844-8.

26. Frost L, Vestergaard P. n-3 Fatty acids consumed from fish and risk of atrial fibrillation or flutter: the Danish Diet, Cancer, and Health Study. The American journal of clinical nutrition. 2005; 81:50-4.

27. Cunha D, Hamlin R, Billman G, Carnes C. n-3 (omega-3) polyunsaturated fatty acids prevent acute atrial electrophysiological remodeling. British journal of pharmacology. 2007; 150:281-5.

28. Laurent G, Moe G, Hu X, Holub B, Leong-Poi H, Trogadis J, Connelly K, Courtman D, Strauss BH, Dorian P. Long chain n-3 polyunsaturated fatty acids reduce atrial vulnerability in a novel canine pacing model. Cardiovascular research. 2007; 77:89-97.

29. Ninio DM, Murphy KJ, Howe PR, Saint DA. Dietary Fish Oil Protects Against Stretch-Induced Vulnerability to Atrial Fibrillation in a Rabbit Model. Journal of cardiovascular electrophysiology. 2005; 16:1189-94.

30. Sarrazin JF, Comeau G, Daleau P, Kingma J, Plante I, Fournier D, Molin F. Reduced incidence of vagally induced atrial fibrillation and expression levels of connexins by $n-3$ polyunsaturated fatty acids in dogs. Journal of the American College of Cardiology. 2007; 50:1505-12.
31. Armaganijan L, Lopes RD, Healey JS, Piccini JP, Nair GM, Morillo CA. Do omega-3 fatty acids prevent atrial fibrillation after open heart surgery? A meta-analysis of randomized controlled trials. Clinics. 2011; 66:1923-8.

32. $\mathrm{Hu}$ YF, Chen YJ, Lin YJ, Chen SA. Inflammation and the pathogenesis of atrial fibrillation. Nature Reviews Cardiology. 2015; 12:230-43.

33. Van Wagoner DR. Oxidative stress and inflammation in atrial fibrillation: role in pathogenesis and potential as a therapeutic target. Journal of cardiovascular pharmacology. 2008; 52:306-13.

34. Katan MB, Deslypere J, Van Birgelen A, Penders M, Zegwaard M. Kinetics of the incorporation of dietary fatty acids into serum cholesteryl esters, erythrocyte membranes, and adipose tissue: an 18-month controlled study. Journal of lipid research. 1997; 38:2012-22.

35. Metcalf RG, James MJ, Gibson RA, Edwards JR, Stubberfield J, Stuklis R, Roberts-Thomson K, Young GD, Cleland LG. Effects of fish-oil supplementation on myocardial fatty acids in humans. The American journal of clinical nutrition. 2007; 85:1222-8.

36. Shamseer L, Moher D, Clarke M, Ghersi D, Liberati A, Petticrew M, Shekelle P, Stewart LA. Preferred reporting items for systematic review and meta-analysis protocols (PRISMA-P) 2015: elaboration and explanation. Bmj. 2015; $349: \mathrm{g} 7647$.

37. Higgins JP, Green S. Cochrane handbook for systematic reviews of interventions: John Wiley \& Sons. 2011.

38. Higgins JP, Thompson SG, Deeks JJ, Altman DG. Measuring inconsistency in meta-analyses. BMJ: British Medical Journal. 2003; 327:557. 